\title{
Investigation of Akuamma Seed Extract on Corrosion Inhibition of Aluminum in Hydrochloric Acid Pickling Environment
}

\author{
J. O. Ezeugo ${ }^{1, *}$, O. D. Onukwuli ${ }^{1,2}$, K. O. Ikebudu ${ }^{3}$, V. C. Ezechukwu ${ }^{3}$ and \\ L. O. Nwaeto $^{3}$
}

${ }^{1}$ Department of Chemical Engineering, Chukwuemeka Odumegwu Ojukwu Universtiy, Anambra State, Nigeria

${ }^{2}$ Department of Chemical Engineering, Nnamdi Azikwe University, Awka, Anambra State, Nigeria

${ }^{3}$ Department of Mechanical Engineering, Chukwuemeka Odumegwu Ojukwu Universtiy, Anambra State, Nigeria

*Corresponding author's e-mail: jn.ezeugo@coou.edu.ng

\begin{abstract}
Inhibitive impact of Akuamma seed (AS) extract toward $1.0 \mathrm{M} \mathrm{HCl}$ corrosion of aluminum was examined using response surface methodology (RSM). Gravimetric (weight loss), potentiodynamic polarization and electrochemical impedance spectroscopy techniques were used in the corrosion inhibition process. In all the method used, the seed extract acted as good corrosion inhibitor of aluminum in $1.0 \mathrm{M} \mathrm{HCl}$ solution. Optimal inhibition efficiency of $72.6 \%$ was obtained at optimum inhibition concentration of $1.2 \mathrm{~g} / \mathrm{l}$, temperature of $304.19 \mathrm{k}$ and maximized time of $11.53 \mathrm{hrs}$. It showed that the plant extract has excellent inhibitive properties for the corrosion inhibition process. The values of $k_{\text {ads }}$ are relatively small indicating that the interaction between the adsorbed extract molecules and aluminum surface is a physical process. The (AS) extract protects aluminum against pitting corrosion. The level of protection increases with increase extract concentrations. The extract inhibited both cathodic and anodic reactions and acted as mixed-type inhibitor.
\end{abstract}

Received: March 5, 2019; Revised: April 4, 2019, Accepted: April 7, 2019

Keywords and phrases: aluminum, corrosion inhibition, Akuamma seed, potentiodynamic polarization, optimization, thermometric.

Copyright (C) 2019 J. O. Ezeugo et al. This is an open access article distributed under the Creative Commons Attribution License, which permits unrestricted use, distribution, and reproduction in any medium, provided the original work is properly cited. 


\section{Introduction}

Corrosion resistance of aluminum is due to the formation of a thin and protective, naturally formed oxide film on its surface $[1,2]$. However, when aluminum is exposed to acidic environment as a result of acid pickling solutions, chemical etching, industrial cleaning or scale dissolution, the oxide film dissolves resulting to significant mass loss of aluminum [3]. In order to prevent and reduce aluminum dissolution, different types of corrosion inhibitors are used, mostly organic compounds, which in their structure contain atoms of nitrogen, sulphur, oxygen, phosphor [4-6]. Although most of the organic compounds have excellent inhibitive performance, their high cost and toxicity are the main setbacks in the use of these compounds as corrosion inhibitors [7, 8]. In recent times, most corrosion inhibitors studies have been focused on the development of "environmental friendly" compounds in response to current trend to legislation changes concerning environmental protection. This term includes formulations that are not toxic to humans, have low environmental impact, optimal biodegradability, and maintenance of high efficiency and cost-effectiveness [9]. Thus since the 1990s, some studies have confirmed the efficiency of natural compounds as corrosion inhibitors in line with the presence of complex organic compounds, with variety of different adsorption centers; heteroatom, double bonds and aromatic rings [10-17].

Akuamma, commonly known as pile plant is a tree that can reach a height of 35 meters but is usually less [18]. It is a commonly used herbal remedy in West Africa [19]. All parts of the plant are bitter throughout its distribution areas; the seeds, bark, leaf and roots are used for pharmaceutical purposes [20]. Considerable researches have been carried out into the medicinal properties, much of it supporting the traditional uses [21]. Akuamma seed contain many organic compounds, such as phenolics, terpenoids and tannins in considerable amount [22]. While saponins, flavornoids and alkaloids are identified in moderate amount to scavenge free radicals and indole detoxification [23, 24]. Before now, there is no reported work on inhibitive effects of Akuamma seed extract on acidic corrosion of aluminum. Hence, the main objective of this work is to investigate the AS extract as potential inhibitor of aluminum corrosion in $1.0 \mathrm{M} \mathrm{HCl}$.

Central composite design (CCD) is an experimental design, applicable mostly in response surface methodology (RSM) for developing a second order (quadratic) model for the response variables without requiring a complete three-level factorial experiment [25]. After the designed experiment is performed using design expert version 10, linear 
regression is used, most times iteratively to obtain results [26]. Coded variables are often used when constructing this design. This study embraced central composite design in the investigation of independent variables, such as concentrations of the acid, concentrations of the inhibitors, temperature and time variations. Dependent variables are referred to, within the context of these studies as expected responses to weight loss, corrosion rate and inhibition efficiency. [26], reported on the effect of critical parameters of corrosion process of mild steel inhibition by plant extracts using design expert 8.1 to model the affect of inhibition process variables of plants extract.

\section{Materials and Methods}

Gravimetric and electrochemical tests were carried out on aluminum alloy (AA3003) specimen with the composition (wt \%): Mn 1.22, Fe 0.55, Si 0.363, Cu 0.017, Pb 0.064, Ti 0.026, V 0.009, and others 0.19, Al 97.672. Each sheet with 0.04 thickness was mechanically pressed cut into coupons of dimensions $2.6 \times 2.6 \mathrm{~cm}$. The coupons were degreased in absolute ethanol, dried in acetone, weighed and stored in moisture free desiccators prior to use.

Thermometric and gravimetric methods were carried out at different temperatures and with various concentrations of the extract. Weighed aluminum alloy coupons were separately immersed in $250 \mathrm{ml}$ open beakers containing $200 \mathrm{ml}$ of $1.0 \mathrm{M} \mathrm{HCl}$. More so, Al coupons were separately immersed in $250 \mathrm{ml}$ open beakers containing $200 \mathrm{ml}$ of $1.0 \mathrm{M}$ $\mathrm{HCl}$ with various concentrations of the AS extract. The variation of weight loss was monitored periodically at various temperatures in the absence and presence of various concentrations of the extract.

At the appropriate time, the aluminum coupons were removed, immersed in acetone, scrubbed with a bristle brush under running water, dried and reweighed. The weight loss was calculated as the difference between the initial weight and the weight after the removal of the corrosion product. Weight loss measurements were undertaken using a FAJA digital weighing balance of the range 0.0001 to $2000 \mathrm{~g}$. The weight measurements were triplicate.

For potentiodynamic polarization and electrochemical impedance spectroscopy, test metal samples of aluminum for electrochemical experiment were machined into cylindrical specimens and fixed in polytetrafluoroethylene (PTFE) rods by epoxy resin in such a way that only one surface of area $1 \mathrm{~cm}^{2}$ was left uncovered. The electrodes used 
were polished with emery papers (400-1200 grits), rinsed with distilled water, degreased and dried. The electrochemical experiment were conducted in a three electrode corrosion cell using a VERSASTAT 400 complete dc voltammetry and corrosion system with V3 studio software for electrochemical impedance spectroscopy and potentiodynamic/ Galvanostat corrosion system with E-chem. software for potentiodynamic polarization experiments. A platinum sheet was used as counter electrode and a saturated calomel electrode (SCE) was used as reference electrode. The calomel electrode was connected via a lugging capillary. Impedance measurements were performed in aerated and unstirred solutions at the end of $1800 \mathrm{~s}$ at $30 \pm 1{ }^{\circ} \mathrm{C}$. The measurements were made at corrosion potentials $\left(\mathrm{E}_{\mathrm{corr}}\right)$ over a frequency range of $100 \mathrm{kHz}-0.1 \mathrm{~Hz}$ with a signal amplitude perturbation of $10 \mathrm{mV}[26,29]$.

Potentiodynamic polarization studies were carried out in the potential range \pm $250 \mathrm{mV}$ versus corrosion potential at a scan rate of $0.5 \mathrm{mVs}^{-1}$. Each test was run in triplicate to verify the reproducibility of the data. All experiments were carried out in freshly prepared solution at constant temperature $30 \pm 1^{\circ} \mathrm{C}$ using a thermostat $[1,30]$.

\section{Results and Discussion}

\section{Weight loss measurements}

Table 1 presents the results of the inhibition efficiency as a function of time and inhibitor (extract) concentration. The inhibition efficiency was time, concentrations and temperature dependent. It increases with increase in extract concentration. Maximum inhibition efficiency of $72.60 \%$ was obtained with inhibition concentration of $1.2 \mathrm{~g} / \mathrm{l}$. similar result was observed by [10, 31]. It showed that the extract of AS has excellent inhibitive ability for the corrosion inhibition process.

Table 1. Result of IE (\%) of $\mathrm{Al}$ in $\mathrm{HCl}$ versus time at various concentrations of $\mathrm{AS}$ extract.

\begin{tabular}{llllllllll}
\hline $\begin{array}{l}\text { Concentration } \\
\left(\mathrm{gl}^{-1}\right)\end{array}$ & 1 & 2 & 4 & 6 & 8 & 12 & 13 & 14 & 15 \\
\cline { 2 - 9 } & & \multicolumn{7}{c}{ Inhibition efficiency, IE (\%) } \\
\hline 0.2 & 27.77 & 30.03 & 35.68 & 37.99 & 39.01 & 40.21 & 40.28 & 40.29 & 40.29 \\
0.45 & 40.11 & 46.00 & 50.23 & 54.61 & 56.12 & 56.24 & 56.3 & 56.3 & 56.31 \\
0.7 & 34.52 & 43.64 & 50.00 & 56.12 & 60.67 & 63.11 & 63.32 & 63.32 & 63.32 \\
0.95 & 35.00 & 47.57 & 55.60 & 60.00 & 67.65 & 70.80 & 70.83 & 70.89 & 70.89 \\
1.2 & 36.11 & 50.03 & 58.88 & 65.22 & 70.04 & 73.60 & 73.60 & 73.60 & 73.60 \\
\hline
\end{tabular}




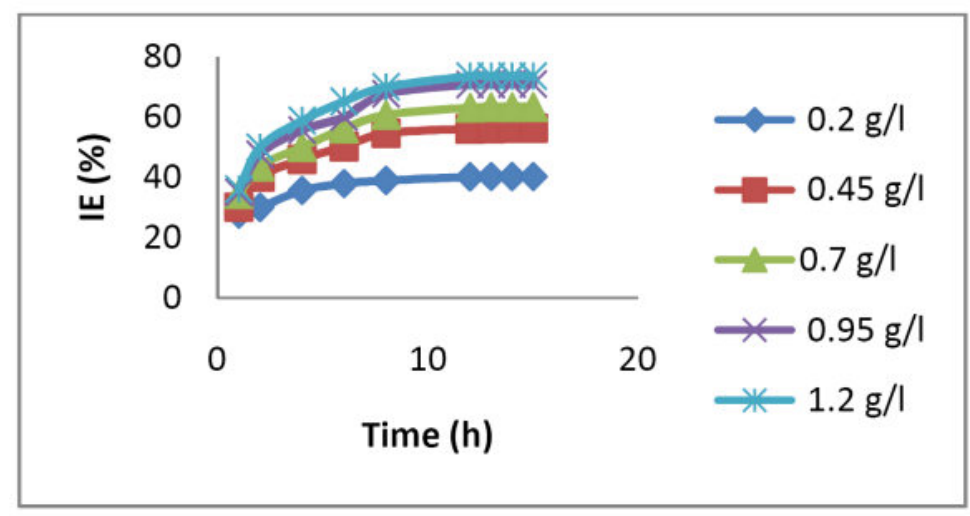

Figure 1. Plot of IE (\%) of $\mathrm{Al}$ in $\mathrm{HCl}$ versus time at various concentrations of AS.

\section{Adsorption studies}

In order to obtain the adsorption isotherm, the degree of surface $(\theta)$ for various concentrations of the inhibitor has been calculated according to the following equation [19].

$$
\theta=\frac{w_{0}-w_{1}}{w_{0}}
$$

where $w_{1}$ and $w_{0}$ are the weight loss values in presence and absence of inhibitor, respectively.

In these studies, Langmuir, Temkin, Frumkin and Flory-Huggins are tested for the AS extract at three temperature ranges of: $303 \mathrm{~K}, 313 \mathrm{~K}$ and $323 \mathrm{~K}$. Straight lines in Figure 2 indicate that the inhibition process obeyed the tested adsorption isotherm. Whereas equations (2)-(5), were used to compute the isotherm properties in Table 2 [20].

Langmuir: $\log \theta / c=\log c-\log k$

Frumkin: $\log c\left(\frac{\theta}{1-\theta}\right)=2.303 \log k+2 x \theta$

Temkin: $\theta=\frac{2.303}{2 a} \log k-\frac{2.303}{2 a} \log c$

Flory-Huggins: $\log \left(\frac{\theta}{c}\right)=\log k+x \log (1-\theta)$ 
where $\theta$ is the degree of surface coverage, $k$ is the equilibrium constant of the adsorption isotherm, $c$ is the concentration of the inhibitor in the bulk solution. The linear regression coefficient is close to unity, hence; adsorption of inhibitor follows Langmuir adsorption isotherms. The adsorption isotherm is based on the assumption that each site of $\mathrm{Al}$ surface holds one molecule of the adsorbed species. Therefore, one adsorbed water molecule is replaced by one molecule of the inhibitor adsorbed on the aluminum surface.

The apparent free energy of adsorption $\left(\Delta \mathrm{G}_{\mathrm{ads}}^{\circ}\right)$ was calculated from the relation;

$$
\Delta \mathrm{G}_{\mathrm{ads}}^{\circ}=-2.303 \mathrm{RT} \log \left(55.5 \mathrm{k}_{\mathrm{ads}}\right)
$$

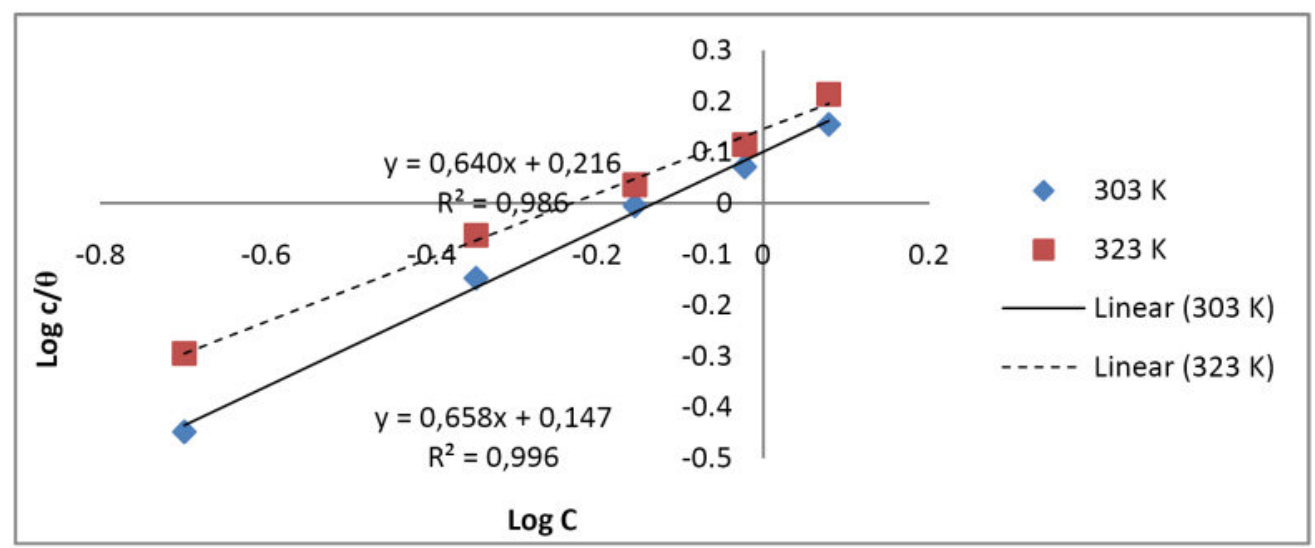

Figure 2. Plot of Langmuir isotherm for aluminum in $\mathrm{HCl}$ with $\mathrm{AS}$ extract.

The thermodynamic parameters are presented in Table 2 . In respect to the fitted data to the Langmuir isotherm, the $\mathrm{R}^{2}$ value is close to unity, indicating excellent adherence to Langmuir adsorption isotherm [32-34]. The negative values of $\Delta \mathrm{G}_{\mathrm{ads}}^{\circ}$ indicate the spontaneous adsorption of the AS extract. The value of the free energy of adsorption is not only negative but is less than the threshold value of $-40 \mathrm{klmol}^{-1}$ required for chemical adsorption. This is in compliance to the previous studies [35-37]. The values of $k_{a d s}$ are relatively small indicating that the interaction between the adsorbed extract of AS molecules and aluminum surface is a physical process. This is also supported by lower negative $\left(\Delta \mathrm{G}_{\mathrm{ads}}^{\circ}\right)$ values for the inhibitor $[38,39]$. 
Table 2. Adsorption parameters for the corrosion inhibition of aluminum in $\mathrm{HCl}$ by Akuamma seed extract.

\begin{tabular}{|l|l|l|l|l|l|l|l|}
\hline $\begin{array}{l}\text { Adsorption } \\
\text { isotherm }\end{array}$ & $\begin{array}{l}\text { Temperature } \\
(\mathrm{K})\end{array}$ & $\mathrm{R}^{2}$ & $\log \mathrm{k}$ & $\mathrm{k}$ & $\begin{array}{l}\Delta \mathrm{G}_{\mathrm{ads}} \\
(\mathrm{KJ} / \mathrm{mol})\end{array}$ & \multicolumn{2}{l|}{ Isotherm property } \\
\hline Langmuir & 303 & 0.986 & -0.216 & 0.6081 & -8.866 & & \\
isotherm & 323 & 0.996 & -0.147 & 0.7129 & -9.878 & & \\
\hline Frumkin & 303 & 0.998 & -1.1038 & 0.0787 & -3.714 & $\alpha$ & 2.068 \\
isotherm & 323 & 0.986 & -1.0512 & 0.0889 & -4.287 & & 2.15 \\
\hline Temkin & 303 & 0.996 & -1.6290 & 0.0235 & -0.669 & $\mathrm{~A}$ & -2.6532 \\
isotherm & 323 & 0.961 & -1.5785 & 0.265 & -1.036 & & -3.0144 \\
\hline Flory-Huggins & 303 & 0.986 & 0.606 & 4.0365 & -13.635 & $\mathrm{X}$ & 1.417 \\
isotherm & 323 & 0.911 & 0.5360 & 3.43 .56 & -14.102 & & 1.865 \\
\hline
\end{tabular}

\section{Results of the potentiodynamic polarization study}

The potentiodynamic polarization curves of $\mathrm{Al}$ in the absence and presence of $\mathrm{AS}$ extract are shown in Figure 3 for the samples in $1.0 \mathrm{M} \mathrm{HCl}$ solution. The values of the polarization parameters are provided in Table 3, where $\mathrm{E}_{\text {corr }}$ and $\mathrm{I}_{\text {corr }}$ are the corrosion potential and current density respectively. They were obtained from the extrapolation of the anodic and cathodic Tafel slopes with respect to the $\mathrm{E}_{\mathrm{corr}}$ values. The results revealed that in the presence of AS extract and at higher concentration of $1000 \mathrm{mgL}^{-1}$ aluminum displayed lower $\mathrm{I}_{\text {corr }}$ and more positive $\mathrm{E}_{\text {corr }}$ values in studied environment. In Table 3, the result shows that the introduction of AS extract reduces both the cathodic and the anodic corrosion current densities, implying that the corrosion rate of $\mathrm{Al}$ sample in the presence of the inhibitor was reduced when compared to the uninhibited Al [40]. Also, the $\mathrm{E}_{\text {corr }}$ of the inhibited $\mathrm{Al}$ is more positive (anodic) than the uninhibited $\mathrm{Al}$. This shows that in the absence of AS extract, Al has a higher susceptibility to corrosion in acidic environment than the uninhibited $\mathrm{Al}$ sample [41]. It is evident that the extract shifts both the anodic and cathodic curves to lower values of current densities [42]. The polarization curves for the $\mathrm{Al}$ samples in $1.0 \mathrm{M} \mathrm{HCl}$ environment exhibited passivation behavior and do not differ in nature of transition from active to passive state [43]. The similarity of the polarization curves of both the uninhibited and inhibited $\mathrm{Al}$ samples indicated that the mechanism of the corrosion of $\mathrm{Al}$ in the absence of the inhibitor did not change even when AS extract was introduced into the aggressive solution [41, 43]. 
Table 3. Parameters obtained from polarization curves at different concentration of inhibitor for $1.0 \mathrm{M} \mathrm{HCl}$

\begin{tabular}{|c|c|c|c|c|}
\hline Concentration $\left(\mathrm{gl}^{-1}\right)$ & $-\mathrm{E}_{\text {corr }}(\mathrm{mV})$ & $\mathrm{I}_{\text {corr }}\left(\mu \mathrm{Acm}^{-2}\right)$ & $\theta$ & $\mathrm{IE}(\%)$ \\
\hline $1.0 \mathrm{M} \mathrm{HCl}$ & 510 & 187.2 & - & - \\
\hline $200 \mathrm{gl}^{-1}$ & 506 & 72.15 & 826 & 82.6 \\
\hline $1000 \mathrm{gl}^{-1}$ & 498 & 31.7 & 892 & 89.2 \\
\hline
\end{tabular}

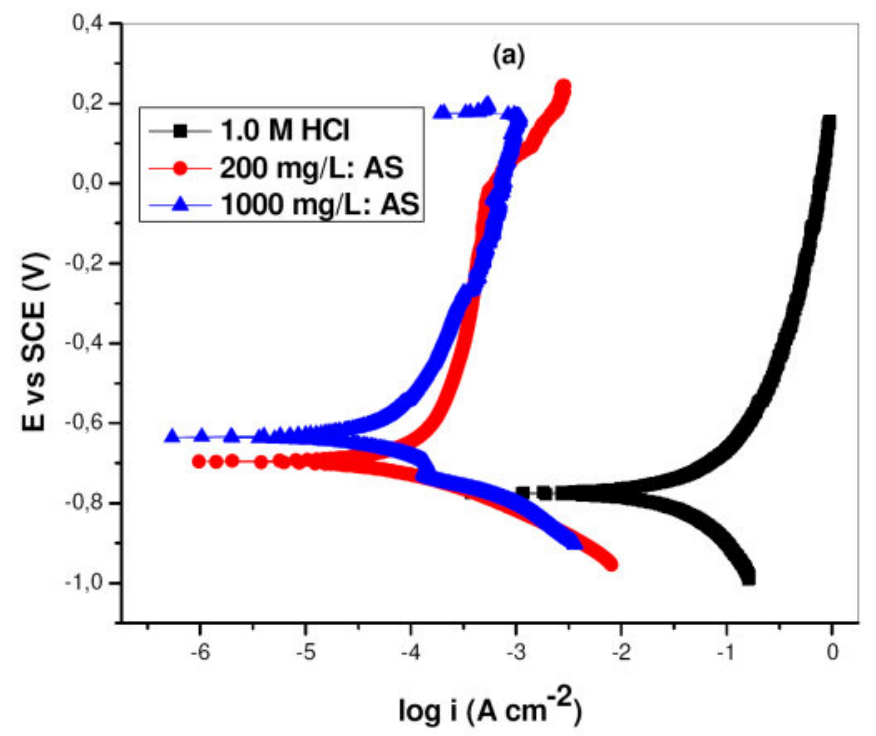

Figure 3. Potentiodynamic polarization curves of aluminum in $1.0 \mathrm{M} \mathrm{HCl}$ in the absence and presence of AS extract.

\section{Impedance spectroscopic results}

Results obtained by impedance spectroscopy are shown in Figure 4. The Nyquist plots showed a capacitive loop followed by an inductive loop for aluminum samples in $1.0 \mathrm{M} \mathrm{HCl}$ solution $[1,44]$. The diameter of the semi circles are related to charge transfer resistance. The size of the capacitive loops was greater in the presence of AS extract, compared to that in inhibitor-free environment, an indication of a higher corrosion resistance for aluminum in the presence of the inhibitor. The occurrence of an inductive loop for the aggressive solutions may indicate certain non-faradic processes, such as adsorption and desorption of corrosion products, occurring at the sample/electrolyte interface. The equivalent circuit model shown in Figure 5 was used to model the 
impedance results obtained for aluminum in $\mathrm{HCl}$ solutions, after fitting with ZSimpWin software. The inductance, $\mathrm{L}$, and charge transfer resistance, $\left(\mathrm{R}_{\mathrm{ct}}\right)$ characterize the processes beneath the store of charges as shown in Table 4. The result shows that the $\mathrm{Q}_{\mathrm{dl}}$ value was lower in the inhibited environment compared to the inhibitor-free aluminum [45]. Similarly; the value of inductance was greater in the inhibited Al sample than for the uninhibited. It shows that introduction of AS extract can modify the electrochemistry of the aluminum sample by reducing the AS penetrations of electrolytes into the substrate electrolyte interface, thus, decreasing the rate of the corrosion in the acid solution [46]. This can also be evidenced by the higher value of $\mathrm{R}_{\mathrm{ct}}$ for $\mathrm{Al}$ in the presence of the inhibitor than the value obtained in the absence of AS [47]. Furthermore, addition of the inhibitor also reduces the rate of penetration of the electrolyte. Hence, the rates of the electrochemical processes in the aluminum electrolyte interface. From the present result, the introduction of the AS extract in the $1.0 \mathrm{M} \mathrm{HCl}$ solution seems to reduce the susceptibility of the Al substrate to dissolution and to the electrochemical processes occurring at the substrate/electrolyte interface. This was made evident by the shift of $E_{c o r r}$ to more positive potentials, the reduction of current densities in the inhibited environment and the increased size of the diameter of the Nyquist plots [48]. It can be deduce that the adsorption of AS extract serve as a barrier blocking the contact between the $\mathrm{Al}$ substrate and the electrolyte solutions.

Table 4. Impedance parameter for aluminum in $1.0 \mathrm{M} \mathrm{HCl}$ in absence and presence of different concentrations of AS extract.

\begin{tabular}{lccccc}
\hline Concentration $\left(\mathrm{gl}^{-1}\right)$ & $\begin{array}{c}\mathrm{R}_{\mathrm{s}} \\
\left(\Omega \mathrm{cm}^{2}\right)\end{array}$ & $\begin{array}{c}\mathrm{R}_{\mathrm{L} 1} \\
\left(\Omega \mathrm{cm}^{2}\right)\end{array}$ & $\begin{array}{c}\mathrm{R}_{\mathrm{ct}} \\
\left(\Omega \mathrm{cm}^{2}\right)\end{array}$ & $\begin{array}{c}\mathrm{Q}_{\mathrm{dl}} \\
\left(\Omega^{-1} \mathrm{~s}^{\mathrm{n}} \mathrm{cm}^{2}\right)\end{array}$ & $\mathrm{L}$ \\
\hline $1.0 \mathrm{M} \mathrm{HCl}$ & 2.36 & 5.7 & 310 & 2.39 & 4.34 \\
200 & 6.06 & 1225 & 1250 & 2.43 & 1218 \\
1000 & 6.94 & 3206 & 3222 & 1.78 & 3228 \\
\hline
\end{tabular}




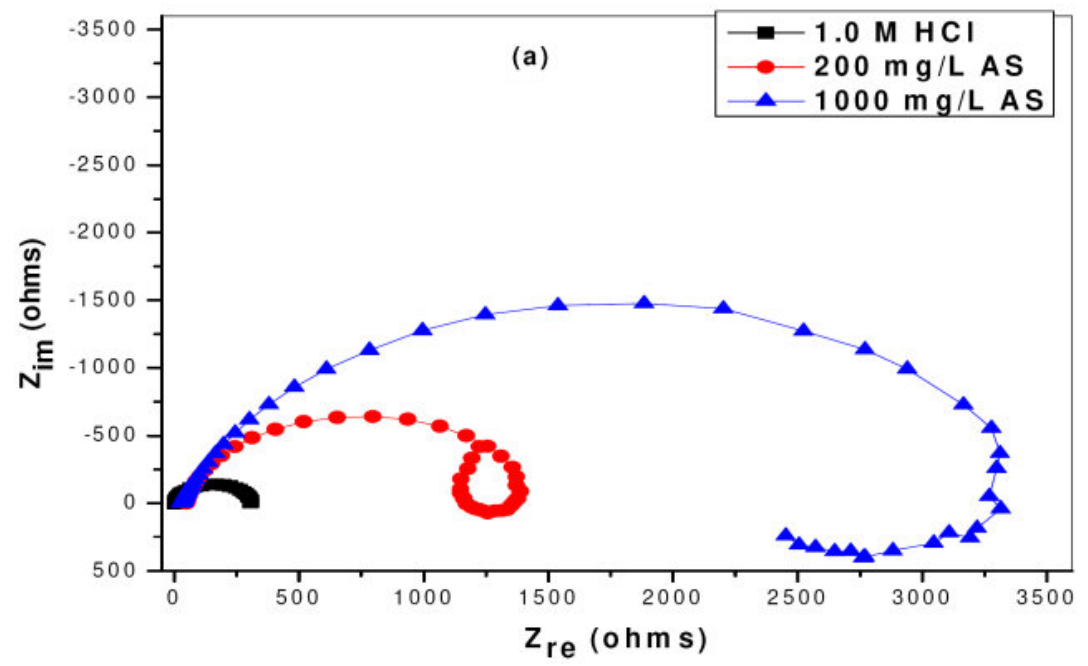

Figure 4(a). Impedance spectra obtained at various concentrations of Akuamma seed extract.

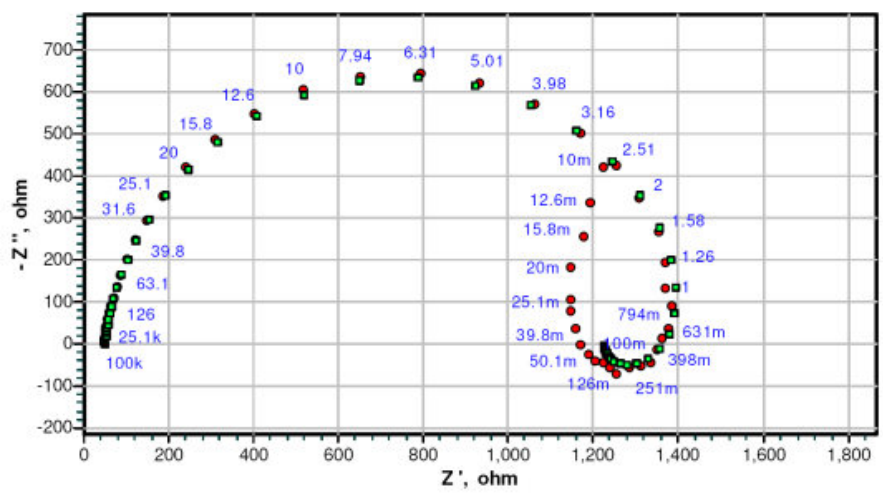

(a)

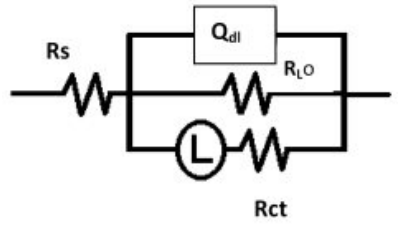

(b)

Figure 5(a, b). Equivalent electrical model for aluminum $\mathrm{HCl}$ with the accompanying experimental.

\section{Results of the gravimetric method using RSM approach}

The expected responses of weight loss, corrosion rate and inhibition efficiency to the independent variables, such as concentration, temperature and time in respect to corrosion inhibition of Akuamma seed extracts as biodegradable corrosion inhibitor for aluminum in $\mathrm{HCl}$ are listed in Table 5. 
Table 5. RSM result of the inhibition of $\mathrm{Al}$ in $\mathrm{HCl}$ medium with $\mathrm{AS}$ extract.

\begin{tabular}{|c|c|c|c|c|c|c|c|c|}
\hline Std & Run & $\begin{array}{l}\text { Factor 1, } \\
\text { A: Acid } \\
\text { Conc. } \\
\text { (M) }\end{array}$ & $\begin{array}{l}\text { Factor 2, } \\
\mathrm{B} \text { : } \\
\text { Inhibitor } \\
\text { Conc. }(\mathrm{g} / \mathrm{l})\end{array}$ & $\begin{array}{l}\text { Factor 3, } \\
\text { C: } \\
\text { Temperature } \\
(\mathrm{K})\end{array}$ & $\begin{array}{l}\text { Factor 4, } \\
\text { D: Time } \\
\text { (hr) }\end{array}$ & $\begin{array}{l}\text { Response } 1 \text {, } \\
\text { Weight Loss } \\
\text { (g) }\end{array}$ & $\begin{array}{l}\text { Response } 2 \text {, } \\
\text { Corrosion } \\
\text { Rate } \\
\left(\mathrm{mg} / \mathrm{cm}^{2} \mathrm{hr}\right)\end{array}$ & $\begin{array}{l}\text { Response 3, } \\
\text { Inhibition } \\
\text { Efficiency } \\
(\%)\end{array}$ \\
\hline 23 & 1 & 1 & 0.7 & 313 & 4 & 0.143 & 3.974 & 56.47 \\
\hline 21 & 2 & 1 & 0.7 & 303 & 8 & 0.107 & 1.49 & 65.15 \\
\hline 13 & 3 & 0.5 & 0.2 & 323 & 12 & 0.429 & 3.974 & 38.5 \\
\hline 27 & 4 & 1 & 0.7 & 313 & 8 & 0.143 & 1.987 & 63.53 \\
\hline 29 & 5 & 1 & 0.7 & 313 & 8 & 0.143 & 1.987 & 63.53 \\
\hline 7 & 6 & 0.5 & 1.2 & 323 & 4 & 0.215 & 5.961 & 47.35 \\
\hline 4 & 7 & 1.5 & 1.2 & 303 & 4 & 0.107 & 2.98 & 63.53 \\
\hline 6 & 8 & 1.5 & 0.2 & 323 & 4 & 0.322 & 8.941 & 33.88 \\
\hline 3 & 9 & 0.5 & 1.2 & 303 & 4 & 0.143 & 3.974 & 50.82 \\
\hline 30 & 10 & 1 & 0.7 & 313 & 8 & 0.143 & 1.987 & 63.53 \\
\hline 22 & 11 & 1 & 0.7 & 323 & 8 & 0.215 & 2.98 & 54.81 \\
\hline 9 & 12 & 0.5 & 0.2 & 303 & 12 & 0.286 & 2.649 & 44.84 \\
\hline 14 & 13 & 1.5 & 0.2 & 323 & 12 & 0.429 & 3.974 & 45.61 \\
\hline 10 & 14 & 1.5 & 0.2 & 303 & 12 & 0.322 & 2.98 & 48.4 \\
\hline 19 & 15 & 1 & 0.2 & 313 & 8 & 0.25 & 3.477 & 47.64 \\
\hline 1 & 16 & 0.5 & 0.2 & 303 & 4 & 0.215 & 5.961 & 33.88 \\
\hline 16 & 17 & 1.5 & 1.2 & 323 & 12 & 0.25 & 2.318 & 61.9 \\
\hline 11 & 18 & 0.5 & 1.2 & 303 & 12 & 0.107 & 0.993 & 69.75 \\
\hline 24 & 19 & 1 & 0.7 & 313 & 12 & 0.215 & 1.987 & 60 \\
\hline 2 & 20 & 1.5 & 0.2 & 303 & 4 & 0.215 & 5.961 & 32.35 \\
\hline 25 & 21 & 1 & 0.7 & 313 & 8 & 0.143 & 1.987 & 63.53 \\
\hline 20 & 22 & 1 & 1.2 & 313 & 8 & 0.107 & 1.49 & 75.42 \\
\hline 26 & 23 & 1 & 0.7 & 313 & 8 & 0.143 & 1.987 & 63.53 \\
\hline 17 & 24 & 0.5 & 0.7 & 313 & 8 & 0.25 & 3.477 & 52.35 \\
\hline 8 & 25 & 1.5 & 1.2 & 323 & 4 & 0.179 & 4.967 & 56.47 \\
\hline 15 & 26 & 0.5 & 1.2 & 323 & 12 & 0.286 & 2.649 & 53.9 \\
\hline 12 & 27 & 1.5 & 1.2 & 303 & 12 & 0.107 & 0.993 & 72.6 \\
\hline 18 & 28 & 1.5 & 0.7 & 313 & 8 & 0.215 & 2.98 & 56.47 \\
\hline 5 & 29 & 0.5 & 0.2 & 323 & 4 & 0.286 & 7.947 & 37.61 \\
\hline 28 & 30 & 1 & 0.7 & 313 & 8 & 0.143 & 1.987 & 63.53 \\
\hline
\end{tabular}

Graphical analysis of the inhibition efficiency, IE (\%) of AS extract as determined using (RSM)

Response surface methodology (RSM) was used to analyze the response of inhibitor concentrations, acid concentrations, time and temperature (independent variables) to 
weight loss, corrosion rate and inhibition efficiency of AS extract on aluminum in acidic environment. The ANOVA and graphical analyses of the inhibition efficiencies of aluminum in $\mathrm{HCl}$ were carried out. The mathematical models for IE (\%) of AS extract for corrosion inhibition of $\mathrm{Al}$ in $\mathrm{HCl}$ solutions in terms of coded and actual factors were obtained. The model (Design expert version 10) in terms of coded factors was used to make predictions about the response for a given levels of each factor. The high levels of the factors were coded as +1 and the low levels of the factors were coded as -1 . The optimum inhibition parameters were obtained and listed in Table 5. From the RSM graphs, Figure 6(a-d); while Figure 6(b) shows IE (\%) of aluminium in $\mathrm{HCl}$ medium with AS extract versus time and acid concentration, Figure 6(c) is a plot of IE (\%) of aluminium in $\mathrm{HCl}$ medium with $\mathrm{AS}$ extract versus temperature and acid concentration. Figure 6(d), predicted versus actual plot is used to test the significance of the model's order (linear graph), while the graphs (3-D surface plots) show the relationship between the factors and responses (inhibition efficiencies) of the designed experiment. Increase in concentration of Akuamma seed extracts, increases the inhibition efficiency of $\mathrm{Al}$ in the aggressive solutions [46-49]. Also inhibition efficiency of the extract reduces as temperature rises [50-54].

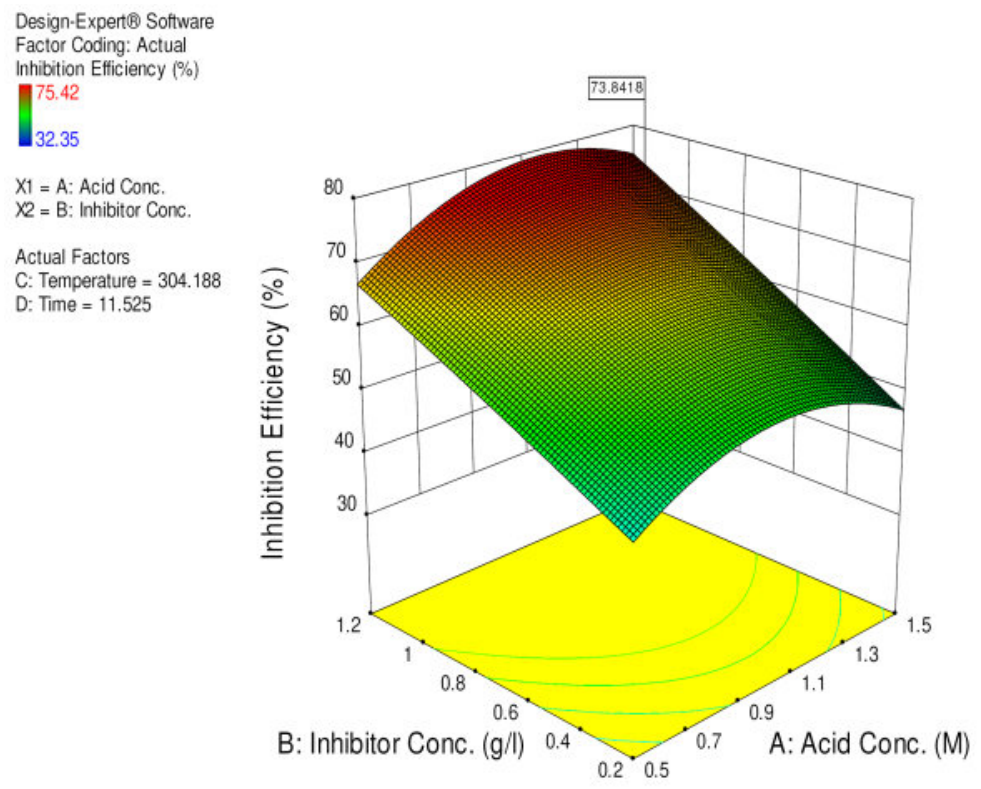

(a) 
Design-Expert(i) Software

Factor Coding: Actual

Inhibition Efficiency (\%)

75.42

$\mathbf{3 2 . 3 5}$

$\mathrm{X} 1=\mathrm{A}:$ Acid Conc.

X $=$ D: Time

Actual Factors

B: Inhibitor Conc. $\equiv 1.14062$

C: Temperature $=304.188$

Design-Expert@ Software

Factor Coding: Actual

Inhibition Efficiency (\%)

75.42

32.35

$\mathrm{X} 1=\mathrm{A}$ : Acid Conc.

$\mathrm{X}_{2}=\mathrm{C}$ : Temperature

Actual Factors

B: Inhibitor Conc. $=1.14062$

D: Time $=11.525$

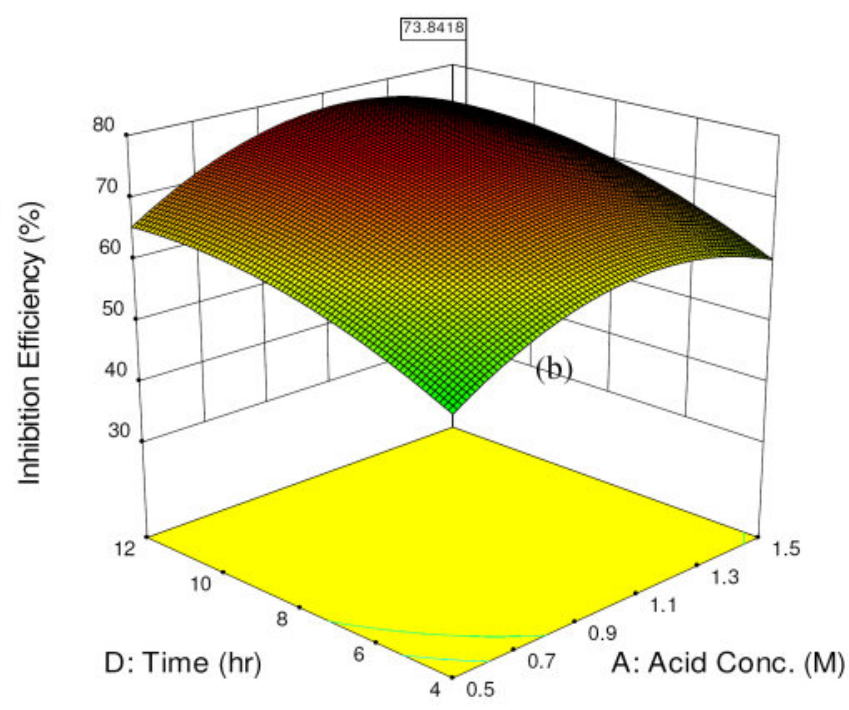

(b)

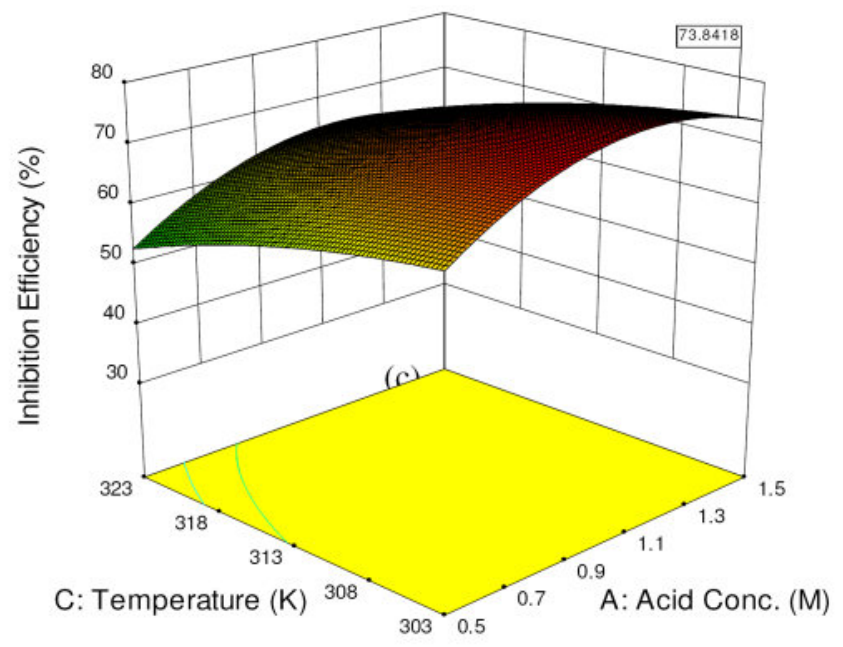

(c) 
Design-Expert( ${ }^{8}$ Software

Inhibition Efficiency

Color points by value of Inhibition Efficiency:

75.42

32.35

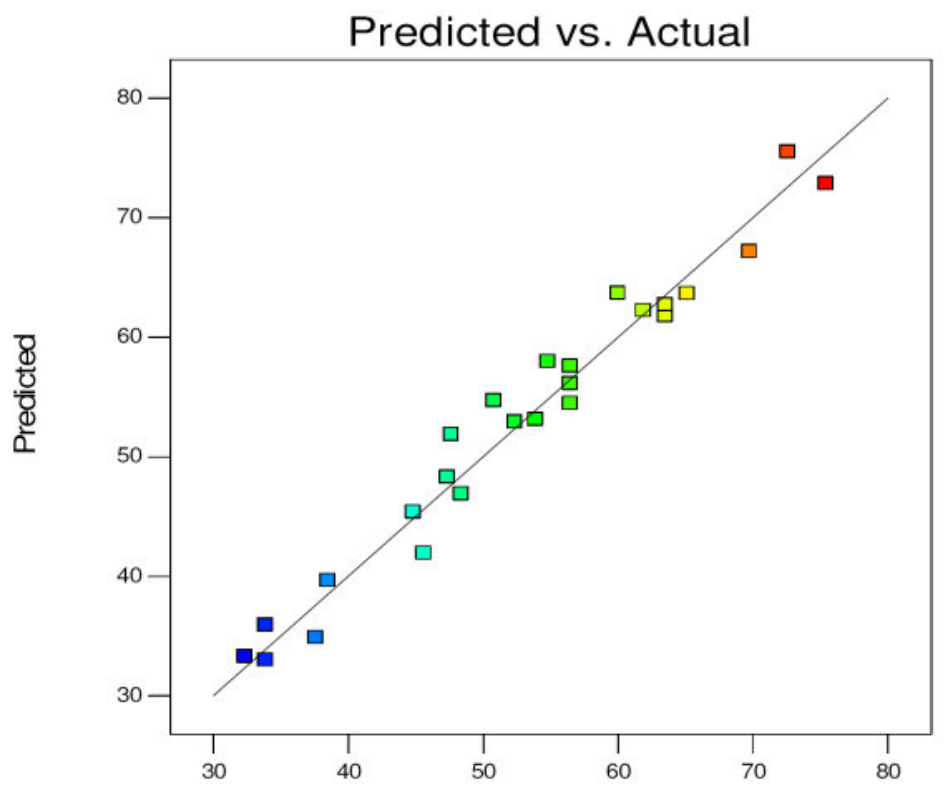

Actual

Figure 6. IE (\%) of aluminum in $\mathrm{HCl}$ medium with $\mathrm{AS}$ extract: (a) Inhibition concentration versus acid concentration. (b) Time versus acid concentration. (c) Temperature versus acid concentration. (d) Predicted versus actual.

From the analysis of variance (ANOVA) for the corrosion inhibition of aluminum in $\mathrm{HCl}$ by AS extract, The Model F-value of 33.01 implies the model is significant. There is only a $0.01 \%$ chance that an F-value this large could occur due to noise. Values of "Prob $>F^{\prime \prime}$ less than 0.0500 indicate model terms are significant. In this case A, B, C, D, AB, $\mathrm{BC}, \mathrm{CD}, \mathrm{A}^{\wedge} 2$ are significant model terms. Values greater than 0.1000 indicate the model terms are not significant. If there are many insignificant model terms (not counting those required to support hierarchy), model reduction may improve your model. The "Pred RSquared" of 0.8049 is in reasonable agreement with the "Adj R-Squared" of 0.9392; i.e. the difference is less than 0.2. "Adeq Precision" measures the signal to noise ratio. A ratio greater than 4 is desirable. Your ratio of 20.803 indicates an adequate signal. This model can be used to navigate the design space. 
Table 6. ANOVA response for inhibition efficiency of $\mathrm{Al}$ in $\mathrm{HCl}$ medium with Akuamma seed extract.

\section{ANOVA for Response Surface Quadratic model}

Analysis of variance table [Partial sum of squares - Type III]

\begin{tabular}{|c|c|c|c|c|c|c|}
\hline & \multirow{2}{*}{ Sum of } & & & & & \\
\hline & & & Mean & $\mathbf{F}$ & p-value & \\
\hline Source & Squares & df & Square & Value & Prob > F & \\
\hline Model & 3860.83 & 14 & 275.77 & 33.01 & $<0.0001$ & significant \\
\hline A-Acid Conc. & 98.98 & 1 & 98.98 & 11.85 & 0.0036 & \\
\hline B-Inhibitor Conc. & 1985.13 & 1 & 1985.13 & 237.59 & $<0.0001$ & \\
\hline C-Temperature & 146.15 & 1 & 146.15 & 17.49 & 0.0008 & \\
\hline D-Time & 384.01 & 1 & 384.01 & 45.96 & $<0.0001$ & \\
\hline $\mathrm{AB}$ & 46.48 & 1 & 46.48 & 5.56 & 0.0323 & \\
\hline $\mathrm{AC}$ & 0.53 & 1 & 0.53 & 0.063 & 0.8047 & \\
\hline $\mathrm{AD}$ & 1.53 & 1 & 1.53 & 0.18 & 0.6746 & \\
\hline $\mathrm{BC}$ & 68.93 & 1 & 68.93 & 8.25 & 0.0116 & \\
\hline $\mathrm{BD}$ & $7.656 \mathrm{E}-003$ & 1 & $7.656 \mathrm{E}-003$ & $9.164 \mathrm{E}-004$ & 0.9762 & \\
\hline $\mathrm{CD}$ & 57.80 & 1 & 57.80 & 6.92 & 0.0189 & \\
\hline $\mathrm{A}^{2}$ & 144.37 & 1 & 144.37 & 17.28 & 0.0008 & \\
\hline $\mathrm{B}^{2}$ & 0.31 & 1 & 0.31 & 0.037 & 0.8503 & \\
\hline $\mathrm{C}^{2}$ & 9.30 & 1 & 9.30 & 1.11 & 0.3081 & \\
\hline $\mathrm{D}^{2}$ & 34.32 & 1 & 34.32 & 4.11 & 0.0608 & \\
\hline Residual & 125.33 & 15 & 8.36 & & & \\
\hline Lack of Fit & 125.33 & 10 & 12.53 & & & \\
\hline Pure Error & 0.000 & 5 & 0.000 & & & \\
\hline Cor Total & 3986.15 & 29 & & & & \\
\hline Std. Dev. & 2.89 & & R-Squared & 0.9686 & & \\
\hline Mean & 54.70 & & Adj R-Squared & 0.9392 & & \\
\hline C.V. \% & 5.28 & & Pred R-Squared & 0.8049 & & \\
\hline PRESS & 777.73 & & Adeq Precision & 20.803 & & \\
\hline \multirow[t]{2}{*}{-2 Log Likelihood } & 128.03 & & $\mathrm{BIC}$ & 179.05 & & \\
\hline & & & $\mathrm{AICc}$ & 192.31 & & \\
\hline
\end{tabular}




\section{Final Equation in Terms of Coded Factors:}

Inhibition Efficiency $=+62.70+2.34 * \mathrm{~A}+10.50 * \mathrm{~B}-2.85 * \mathrm{C}+4.62 * \mathrm{D}+1.70 * \mathrm{AB}+0.18 *$ $\mathrm{AC}+0.31 * \mathrm{AD}-2.08 * \mathrm{BC}+0.022 * \mathrm{BD}-1.90 * \mathrm{CD}-7.46 * \mathrm{~A}^{2}-0.34 * \mathrm{~B}^{2}-1.89 * \mathrm{C}^{2}-3.64 * \mathrm{D}^{2}$

\section{Final Equation in Terms of Actual Factors:}

Inhibition Efficiency $=-1970.56508+47.01277 *$ Acid Conc. $+145.96298 *$ Inhibitor Conc. $+12.21045 *$ Temperature $+19.50451 *$ Time+6.81750* Acid Conc. * Inhibitor Conc. $+0.036375 *$ Acid Conc. * Temperature $+0.15469 *$ Acid Conc. * Time- $0.41512 *$ Inhibitor Conc. * Temperature+0.010938* Inhibitor Conc. * Time-0.047516* Temperature * Time-29.85895* Acid Conc. ${ }^{2}-1.37895 *$ Inhibitor Conc. ${ }^{2}-0.018947 *$ Temperature $^{2}-0.22748 *$ Time $^{2}$

\section{Results of the optimum inhibition efficiency}

To confirm the validity of the results of corrosion inhibition of aluminium by AS extract in $\mathrm{HCl}$, additional experimental were conducted. The chosen conditions for the concentration, temperature and time are listed in Table 7, along with the predicted and measured inhibited efficiencies. As shown in Table 7, the measured inhibition efficiencies were close to the predicted values. It shows that RSM approach was appropriate for optimizing the corrosion inhibition process and the result showed that the optimum inhibition efficiency of the AS extract is $72.60 \%$.

Table 7. Validation of result for corrosion inhibition of $\mathrm{Al}$ in $\mathrm{HCl}$ by AS extract

\begin{tabular}{|l|l|l|l|l|l|l|l|l|}
\hline S/N & Inhibitor & $\begin{array}{l}\text { Acid } \\
\text { Conc. }\end{array}$ & $\begin{array}{l}\text { Inhibitor } \\
\text { Conc. } \\
(\mathrm{g} / \mathrm{l})\end{array}$ & $\begin{array}{l}\text { Temperature } \\
(\mathrm{K})\end{array}$ & $\begin{array}{l}\text { Time } \\
(\mathrm{hr})\end{array}$ & $\begin{array}{l}\text { Predicted } \\
\text { IE }(\%)\end{array}$ & $\begin{array}{l}\text { Experimental } \\
\text { IE (\%) }\end{array}$ & $\begin{array}{l}\text { Percentage } \\
\text { error }(\%)\end{array}$ \\
\hline 1 & AS & 1.48 & 1.14 & 304.19 & 11.53 & 73.84 & 72.6 & 1.6 \\
\hline
\end{tabular}

FT IR analysis on Akuamma seed pure extract and corrosion product from $\mathrm{HCl}$ environment

Figures 7 and 8 present the analysis of pure AS extract and corrosion product of Aluminum in $\mathrm{HCl}$ with the AS extract. The results revealed that the stretch bond of $3971.7 \mathrm{~cm}^{-1}$ to $3539.38 \mathrm{~cm}^{-1}$ represent the strong, sharp and broad free bond of alcohol. The wave $\mathrm{b}$ and range of $3477.62 \mathrm{~cm}^{-1}$ to $3354.1 \mathrm{~cm}^{-1}$ represent medium and often broad 
stretch of amine or amide group $3261.46 \mathrm{~cm}^{-1}$ wave band represent strong and sharp bond of alkyne. 3172.68 to 2925.64 range of waveband represent variable stretch of alkyl and aromatic group. Wave bands $2798.26 \mathrm{~cm}^{-1}$ to $2582.1 \mathrm{~cm}^{-1}$ represent very broad signal centered near wave band of $3,000 \mathrm{~cm}^{-1}$ of free bond of alcohol. Wave bands $2493.32 \mathrm{~cm}^{-1}$ to $7211.44 \mathrm{~cm}^{-1}$ represent variable and sharp stretch of alkenes and nitrite. $2122.76 \mathrm{~cm}^{-1}$, $2030.12 \mathrm{~cm}^{-1}$ wave band are for variable and sharp stretch bond of alkynes. Those of $1902.74 \mathrm{~cm}^{-1}$ to $1659.56 \mathrm{~cm}^{-1}$ stand for that of very strong stretch of acids, esters, anhydrides. Wave band $1566.92 \mathrm{~cm}^{-1}$ represent medium and strong bond of amines and amides while wave band of $1497 / 44 \mathrm{~cm}^{-1}$ to $1319.24 \mathrm{~cm}^{-1}$ are strong stretch of alkyl bonding groups. The range of wave band that stretched from to $1227.24 \mathrm{~cm}^{-1}$ to $1072.84 \mathrm{~cm}^{-1}$ are strong stretch of acids, esters and anhydrides.

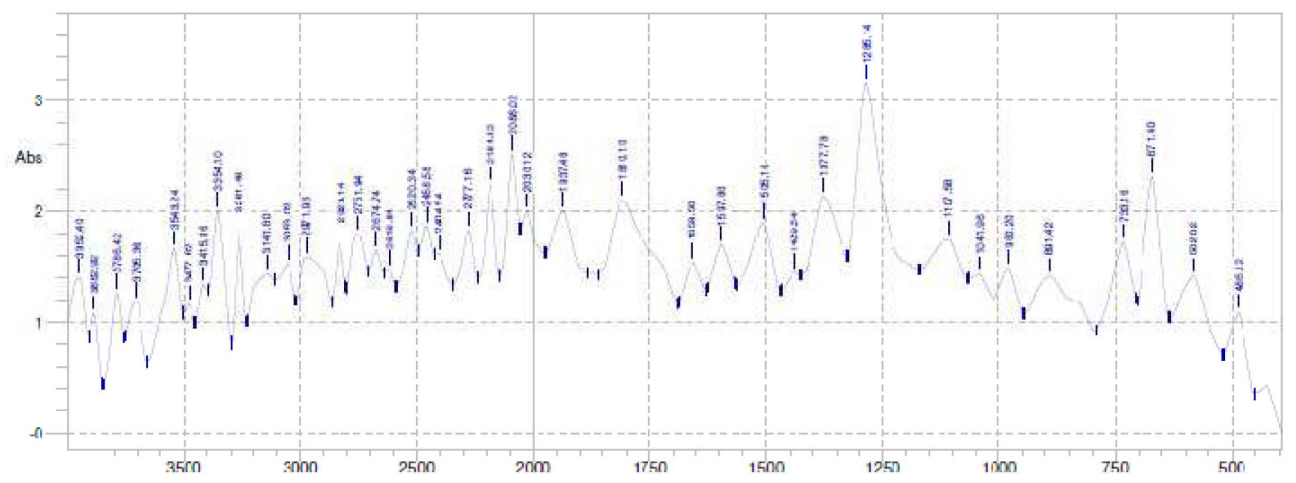

Figure 7. FT IR analysis of pure extract of Akuamma seed.

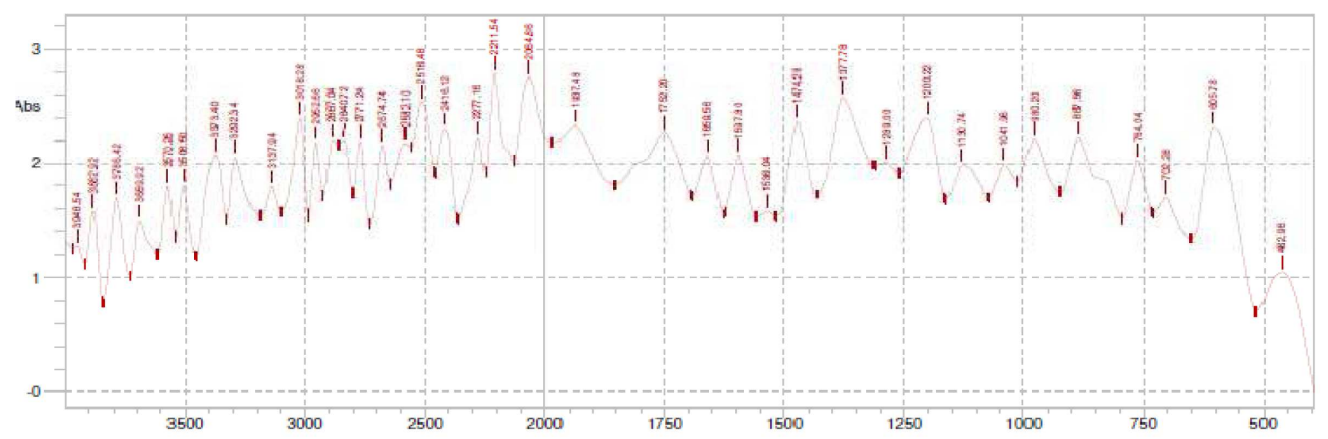

Figure 8. FT IR analysis of corroded product of Akuamma seed extract. 
AS pure extract contain some essential organic compounds which have good inhibitory properties capable of replacing $\mathrm{O}_{2}, \mathrm{H}_{2} \mathrm{~S}$ and $\mathrm{N}$ with amines, nitrite, hydroxyl and benzene at the aluminum surface interphase. The changes of the wave band and the nature of the shifts indicate that there was synergy among the functional groups in the corrosion inhibition process [49-53].

\section{Surface morphology}

Optical microscope test, Figure 9, revealed that when a smooth surface of aluminum alloy is immersed in $1.0 \mathrm{M} \mathrm{HCl}$ solution, in absence of AS extract, corrosion pits were created on the surface of the aluminum due to aggressive attack of the $\mathrm{HCl}$ solution [1, 56]. A rough surface with flakes of dark color is observed, Figure 9(a), which indicates deposition of corrosion products and/or chloride ions on the surface. But in the presence of inhibitor as shown in Figure 9(b), smooth layers were observed due to adsorption of organic species present in the extract at most active sites [55] reported similar observation. On the basis of the information provided by the optical microscope, it can be concluded that plant extract protect aluminum surface in hydrochloric acid environment forming good protective film on the surface of the metal. This trend was previously reported by other researchers [57]. The outcome of this process revealed that the adsorption of the extract is spontaneous, stable and follows the mechanism of physical adsorption $[26,55]$.

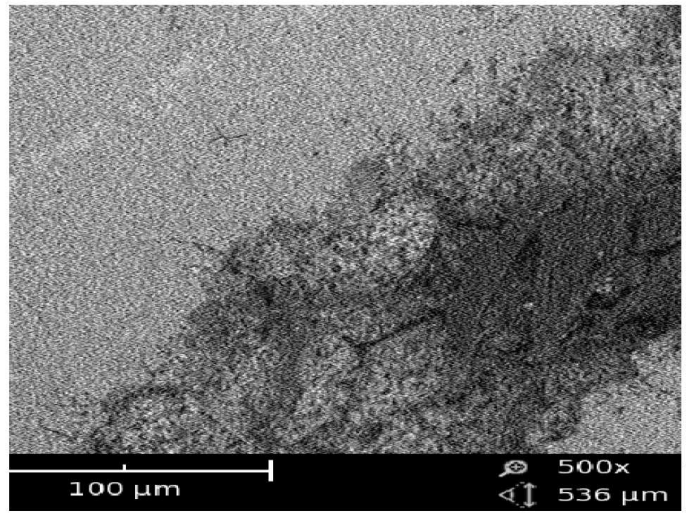

(a)

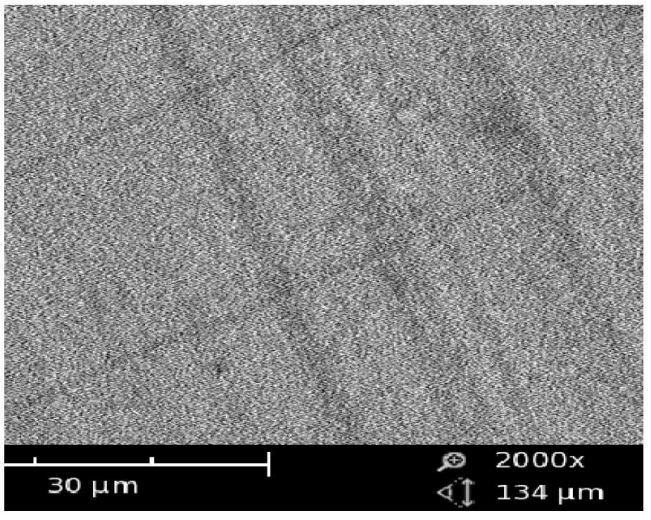

(b)

Figure 9. Micro photographs obtained by optical microscope for surface morphology of aluminum in: (a) corroded in $1.0 \mathrm{MHCl}$ and (b) $1.0 \mathrm{MHCl}$ with $1000 \mathrm{gl}^{-1}$ inhibitor concentration. 


\section{Conclusion}

From the gravimetric method, maximum inhibition efficiency of $73.60 \%$ was obtained with inhibition concentration of $1.2 \mathrm{~g} / \mathrm{l}$. It showed that the extract of AS has excellent inhibitive ability for the corrosion inhibition process. The adsorption process of AS extract on the surface of the aluminum is spontaneous, stable and follows Langmuir adsorption isotherm. The values of $\mathrm{k}_{\mathrm{ads}}$ are relatively small indicating that the interaction between the adsorbed extract of AS molecules and aluminum surface is a physical process. The extract protected the AS aluminum against pitting corrosion. The level of protection increases with increasing extract concentration. The extract inhibited both cathodic and anodic reactions and acted as mixed-type inhibitor.

\section{References}

[1] Rajesh Haldhar, Dwarika Prasad and Akhil Saxena, Armoracia rusticana as sustainable and eco-friendly corrosion inhibitor for mild steel in $0.5 \mathrm{M}$ sulphuric acid: Experimental and theoretical investigations, Journal of Environmental Chemical Engineering 6 (2018), $5230-5238$.

[2] J. Ezeugo, O. D. Onukwuli and M. Omotioma, Adsorption kinetics of Picralima nitida leaf extract as a green corrosion inhibition for zinc in $0.5 \mathrm{M} \mathrm{H} 2 \mathrm{SO} 4$, Equatorial Journal of Chemical Sciences 2 (2018), 13 pp.

[3] S. A. Umoren, U. M. Eduok, A. U. Israel, I. B. Obot and M. M. Solomon, Coconut coir dust extract: a novel eco-friendly corrosion inhibitor for $\mathrm{AI}$ in $\mathrm{HCl}$ solutions, Green Chemistry Letters \& Rev. 5 (2012), 303-313.

[4] Nnabuk O. Eddy, H. Momoh-Yahaya and Emeka E. Oguzie, Theoretical and experimental studies on the corrosion inhibition potentials of some purines for aluminium in $0.1 \mathrm{M}$ HCl, Journal of Advance Research 6 (2015), 203-217.

[5] Ihebrodike M. Mejeha, Michael C. Nwandu, Kelechukwu B. Okeoma, Lebe A. Nnanna, Maduabuchi A. Chidiebere, Francis C. Eze and Emeka E. Oguzie, Experimental and theoretical assessment of the inhibiting action of Aspilia africana extract on corrosion of aluminium alloy AA3003 in hydrochloric acid, J. Materials Science 47 (2012), 25592572 .

[6] A. Y. El-Etre, Inhibition of aluminium corrosion using Opuntia extract, Corrosion Science 45 (2003), 2485-2495. 
[7] K. F. Khaled, Adsorption and inhibitive properties of a new synthesized guanidine derivative on corrosion of copper in 0.5 $\mathrm{M} \mathrm{H}_{2} \mathrm{SO}_{4}$, Applied Surface Science 255 (2008), 1811-1818.

[8] M. A. Migahed, A. M. Abdul-Raheim, A. M. Atta and W. Brostow, Synthesis and evaluation of a new water soluble corrosion inhibitor from recycled poly(ethylene terphethalate), Material Chemistry and Physics 121 (2010), 208-214.

[9] Narayana Hebbar, B. M. Praveen, B. M. Prasanna, T. V. Venkatesha, S. B. Abd Hamide, Anthranilic acid as corrosion inhibitor for mild steel in hydrochloric acid media, Procedia Material Science 5 (2014), 712-718.

[10] Sayed S. Abdel Rehim, Omar A. Hazzazi, Mohammed A. Amin and Khaled F. Khaled, On the corrosion inhibition of low carbon steel in concentrated sulphuric acid solutions. Part1: Chemical and electrochemical (AC and DC) studies, Corrosion Science 50 (2008), 2258-2271.

[11] Shaily M. Bhola, Faisal M. Alabbas, Rahul Bhola, John R. Spear, Brajendra Mishra, David L. Olson and Anthony E. Kakpovbia, Neem extract as an inhibitor for biocorrosion influenced by sulfate reducing bacteria: A preliminary investigation, Engineering Failure Analysis 36 (2014), 92-103.

[12] V. V. Torres, R. S. Amado, C. Faia de Sa, T. L. Fernandez, Carlos A. da Silva Riehl, A. G. Torres and E. D'Elia, Inhibitory action of aqueous coffee ground extracts on the corrosion of carbon steel in $\mathrm{HCl}$ solution, Corrosion Sci. 53 (2011), 2385-2392.

[13] P. F. Khan, V. Shanthi, R. K. Babu, S. Muralidharan and R. C. Barik, Effect of benzotriazole on corrosion inhibition of copper under flow conditions, J. Env. Chem. Eng. 3 (2015), 10-19.

[14] Aprael S. Yaro, Anees A.Khadom and Rafal K. Wael, Apricot juice as green corrosion inhibitor of mild steel in phosphoric acid, Alexandria Engineering Journal 52 (2013), $129-135$.

[15] J. E. Saxton, Alkaloids of Picralima nitida, in: Manske R. H. F., ed., The Alkaloids: Chemistry and Physiology, Vol. 8, New York: Academic Press, 1960, pp. 122-129.

[16] H. M. Burkill, The Useful Plants of West Tropical Africa, 2nd ed., Kew: Royal Botanical Gardens, 1985, pp. 456-596.

[17] J. E. Ajanohoun, N. Aboubakar, K. Diamante, M. E. Ebot, J. A. Ekpere, E. G. EnowOrock, et al., Contribution to ethnobotanical and floristic studies in Cameroon, Traditional medicine and Pharmacopoeia, Technical and Research Commission of the Organization of African Unity, OAU/STRC, 1996, pp. 60-61. 
[18] Nigeria Natural Medicine Development Agency (Federal Ministry of Science and Technology), Medicinal plants of Nigeria, South-East Zone, 2008, pp. 8-159.

[19] J. M. Dalziel, The Useful Plants of West Tropical Africa, London: The Crown Agents for the Colonies, 1937, pp. 18-22.

[20] M. Iwu, Handbook of African Medicinal Plants, U.S.A.: CRC Press Inc., 1993, pp. 219221 .

[21] G. J. Kapadia, C. K. Angerhofer and R. Ansa-Asamoah, Akuammine: an antimalarial indolemonoterpene alkaloid of Picralima nitida seeds, Planta Med. 59 (1993), 565-566.

[22] I. Etukudo, Conventional and Traditional Uses of Plants, Ethnobotany, vol. 1, Uyo The Verdict Press, 2003, p. 191.

[23] L. B. Kouitcheu, J. Kouam, P. Atangana and F. X. Etoa, Phytochemical screening and toxicological profile of methanolic extract of Picralima nitida fruit-rind (Apocynaceae), Toxicol. Environ. Chem. 90 (2008), 815-828.

[24] J. R. Ainslie, A List of Plants used in Native Medicine in Nigeria, Imperial Forestry Institute, Oxford Institute Paper, 1937, p. 7.

[25] J. E. Saxton, Alkaloids of Picralima nitida, in: Manske RHF, editor, The Alkaloids: Chemistry and Physiology, Vol. 8, New York: Academic Press, 1965, 119-158.

[26] J. N. O. Ezeugo, O. D. Onukwuli and M. Omotioma, Optimization of corrosion inhibition of Picralima nitida leaves extract as green corrosion inhibitor for zinc in $1.0 \mathrm{HCl}$, World News of Natural Sci. 15 (2017), 139-161.

[27] S. S. Abdel-Rehim, K. F. Khaled and N. A. Al-Mobarak, Corrosion inhibition of iron in hydrochloric acid using pyrazole, Arabian Journal of Chemistry 4 (2011), 333-337.

[28] Patchaiah Kalaiselvi, Subbiah Chellammal, Seeni Palanichamy and Gopalan Subramanian, Artemisia pallens as corrosion inhibitor for mild steel in $\mathrm{HCl}$ medium, Materials Chemistry and Physics 120 (2010), 643-648.

[29] M. S. Al-Otaibi, A. M. Al-Mayouf, M. Khan, A. A. Mousa, S. A. Al-Mazroa and H. Z. Alkhathlan, Corrosion inhibitory action of some plant extracts on the corrosion of mild steel in acidic media, Arabian Journal of Chemistry 7 (2014), 340-346.

[30] Matjaž Finšgar and Jennifer Jackson, Application of corrosion inhibitors for steels in acidic media for the oil and gas industry, a review, Corrosion Science 86 (2014), 17-41.

[31] Chris O. Akalezi, Emeka E. Oguzie, Cynthia E. Ogukwe and Everest A. EJele, Rothmannia longiflora extract as corrosion inhibitor for mild steel in acidic media, Int. J. Ind. Chem. 6 (2015), 273-284. 
[32] E. E. Oguzie, Z. O. Iheabunike, K. L. Oguzie, C. E. Ogukwe, M. A. Chidiebere, C. K. Enenebeaku and C. O. Akalezi, Corrosion Inhibiting Effect of Aframomum melegueta Extracts and Adsorption Characteristics of the Active Constituents on Mild Steel in Acidic Media, Journal of Dispersion Science and Technology 34 (2013), 516-527.

[33] Abd El-Aziz S. Fouda, Ahmed Abdel Nazeer, Ayman Y. El-Khateeb, Mohamed Fakih, Cinnamon plant extract as corrosion inhibitor for steel used in waste water treatment plants and its biological effect on Escherichia coli, Journal of the Korean Chemical Society 58 (2014), 359-365.

[34] E. I. Ating, S. A. Umoren, I. I. Udousoro, E. E. Ebenso and A. P. Udoh, Leaves extract of Ananas sativum as green corrosion inhibitor for aluminium in hydrochloric acid solutions, Green Chemistry Letters and Reviews 3 (2010), 61-68.

[35] S. K. Sharma, Anjali Peter and Ime Bassey Obot, Potential of Azadirachta indica as a green corrosion inhibitor against mild steel, aluminum, and tin: a review, Journal of Analytical Science and Technology 6 (2015), 26.

[36] E. E. Oguzie, Evaluation of the inhibitive effect of some plant extracts on the acid corrosion of mild steel, Corrosion Sci. 50 (2008), 2993-2998.

[37] G. Quartarone, L. Ronchin, A. Vavasori, C. Tortato and L. Bonaldo, Inhibitive action of gramine towards corrosion of mild steel in deaerated $1.0 \mathrm{M}$ hydrochloric acid solutions, Corrosion Sci. 64 (2012), 82-89.

[38] Z. Hu, Y. Meng, X. Ma, H. Zhu, J. Li, C. Li and D. Cao, Experimental and theoretical studies of benzothiazole derivatives as corrosion inhibitors for carbon steel in $1.0 \mathrm{M} \mathrm{HCl}$, Corrosion Sci. 112 (2016), 563-575.

[39] P. Thilagavathy and R. Saratha, Mirabilis Jalapa flowers extract as corrosion inhibitor for the mild steel corrosion in 1M HCL, IOSR Journal of Applied Chemistry 8 (2015), 30-35.

[40] R. Kumar, O. S. Yadav and G. Singh, Electrochemical and surface characterization of a new eco-friendly corrosion inhibitor for mild steel in acidic media: a cumulative study, $J$. Mol. Liq. 237 (2017), 413-427.

[41] M. A. Ameer and A. M. Fekry, Corrosion inhibition of mild steel by natural product compound, Progress in Organic Coating 71 (2011), 343-349.

[42] N. O. Eddy, S. A. Odoemelam and I. N. Ama, Ethanol extract of Ocimum gratissimum as a green corrosion inhibitor for the corrosion of mild steel in $\mathrm{H}_{2} \mathrm{SO}_{4}$, Green Chem. Lett. Rev. 3 (2010), 165-172.

[43] K. F. Khaled, Studies of iron corrosion inhibition using chemical, electrochemical \& computer simulation techniques, Electrochimica Acta 55 (2010), 6523-6532. 
[44] A. S. Fouda, K. Shalabi and A. A. Idress, Ceratonia siliqua extract as a green corrosion inhibitor for copper and brass in nitric acid solutions, Green Chemistry Letters \& Reviews 8 (2015), 17-29.

[45] J. N. O. Ezeugo, O. D. Onukwuli and M. Omotioma, Inhibition of aluminium corrosion in 1.0 M HCl using Picralima nitida leaves extract, Der Pharma Chemica 10(S1) (2018), 713.

[46] O. O. Dominic and O. Monday, Optimization of the inhibition efficiency of mango extract as corrosion inhibitor of mild steel in $1.0 \mathrm{M} \mathrm{H}_{2} \mathrm{SO}_{4}$ using response surface methodology, $J$. Chem. Tech. Metallurgy 51 (2016), 302-314.

[47] A. Ehsani, R. Moshrefi and M. Ahmadi, Electrochemical investigation of inhibitory of new synthesized 3-(4-iodophenyl)-2-imino-2,3-dihydrobenzo[d]oxazol-5-yl 4methylbenzenesulfonate on corrosion of stainless steel in acidic medium, J. Electrochem. Sci. Technol. 6 (2015), 7-15.

[48] O. D. Onukwuli and J. O. Ezeugo, Plant extract as biodegradable inhibitor for zinc in dilute solution of sulphuric acid, World Scientific News 109 (2018), 195-210.

[49] Z. V. P. Murthy and K. Vijayaragavan, Mild steel corrosion inhibition by acid extract of leaves of Hibiscus sabdariffa as a green corrosion inhibitor and sorption behavior, Green Chemistry Letters and Reviews 7 (2014), 209-219.

[50] S. A. Umoren, U. M. Eduok, M. M. Solomon and A. P. Udoh, Corrosion inhibition by leaves and stem extracts of Sida acuta for mild steel in $1 \mathrm{M} \mathrm{H}_{2} \mathrm{SO}_{4}$ solution investigated by chemical and spectroscopic techniques, Arabian Journal of Chemistry 9 (2016), S209S224.

[51] K. F. Khaled, Corrosion control of copper in nitric acid solutions using some amino acids - A combined experimental and theoretical study, Corrosion Science 52 (2010), 32253234.

[52] M. Metikos-Hukovic, R. Babic and Z. Grubac, The study of aluminium corrosion in acidic solution with nontoxic inhibition, J. Appl. Electrochem. 32 (2002), 35-41.

[53] F. Bentiss, M. Traisnel and M. Lagrenee, The substituted 1,3,4-oxadiazoles: a new class of corrosion inhibitors of mild steel in acidic media, Corros. Sci. 42 (2000), 127-146.

[54] C. Kamal and M. G. Sethuraman, Spirulina platensis - A novel green inhibitor for acid corrosion of mild steel, Arab J. Chem. 5 (2012), 155-161.

[55] N. O. Eddy, Adsorption and inhibitive properties of ethanol extract of Garcinia kola and Cola nitida for the corrosion of mild steel in $\mathrm{H}_{2} \mathrm{SO}_{4}$, Pigment \& Resin Technology 39 (2010), 348-354. 
[56] Akhil Saxena, Dwarika Prasad and Rajesh Haldhar, Use of Asparagus racemosus extract as green corrosion inhibitor for mild steel $0.5 \mathrm{M} \mathrm{H}_{2} \mathrm{SO}_{4}$, J. Mater. Sci. 53 (2018), 85238535 .

[57] Rajesh Haldhar, Dwarika Prasad, Akhil Saxena and Priyanka Singh, Valeriana wallichii root extract as a green \& sustainable corrosion inhibitor for mild steel in acidic environments: experimental and theoretical study, Mater. Chem. Front. 2 (2018), 12251237. 